\title{
Coping and work engagement in selected South African organisations
}

\author{
Authors: \\ Sebastiaan Rothmann ${ }^{1}$ \\ Lene I. Jorgensen ${ }^{2}$ \\ Carin Hill ${ }^{3}$

\section{Affiliations:} \\ ${ }^{1}$ Optentia Research \\ Programme, North-West \\ University, Vanderbijlpark \\ Campus, South Africa \\ ${ }^{2}$ WorkWell, Research Unit for \\ Economic and Management \\ Sciences, North-West \\ University, Potchefstroom \\ Campus, South Africa \\ ${ }^{3}$ Department of Industrial \\ Psychology and People \\ Management Industrial \\ Psychology, University of \\ Johannesburg, South Africa \\ Correspondence to: \\ Sebastiaan Rothmann \\ Email: \\ ian@ianrothmann.com \\ Postal address: \\ Faculty of Humanities, \\ North-West University, PO \\ Box 1174, Vanderbijlpark \\ 1900, South Africa

\section{Dates:} \\ Received: 31 Aug. 2010 \\ Accepted: 08 July 2011 \\ Published: 12 Oct. 2011 \\ How to cite this article: \\ Rothmann, S., Jorgensen, L.I., \\ \& Marais, C. (2011). Coping \\ and work engagement in \\ selected South African \\ organisations. SA Journal \\ of Industrial Psychology/SA \\ Tydskrif vir Bedryfsielkunde, \\ 37(1), Art. \#962, 11 pages. \\ doi:10.4102/sajip.v37i1.962
}

C 2011. The Authors. Licensee: AOSIS OpenJournals. This work is licensed under the Creative Commons Attribution License.
Orientation: The coping strategies of their employees are amongst the activities that organisations should address to improve their employees' work engagement.

Research purpose: The objective of this study was to investigate the relationship between coping strategies and work engagement in three occupational groups in South Africa.

Motivation for the study: There is little understanding of the relationship between effective forms of coping and positive outcomes (like work engagement).

Research design, approach and method: The researchers used a survey design. They drew random and stratified samples $(N=3178)$ from three occupational groups. These were technical employees in an electricity provider, professional and enrolled nurses and police officers. They administered the Coping Orientations to the Problems Experienced (COPE) and the Utrecht Work Engagement Scale (UWES).

Main findings: The results showed that there was a statistically significant relationship between work engagement, problem-focused coping, positive reinterpretation and growth. In the nursing sample, high problem-focused coping, low avoidance and low ventilation of emotions predicted work engagement best. In the police sample, four coping strategies (problem-focused coping, seeking social support, turning to religion and low ventilation of emotions) predicted work engagement best. In the technician sample, problem-focused coping and low ventilation of emotions predicted work engagement best.

Practical/managerial implications: Organisations should consider employees' coping strategies when they introduce interventions to improve work engagement.

Contribution/value-add: This study contributes to the knowledge about the relationship between coping strategies and work engagement in South African organisations.

\section{Introduction}

The subjective well-being of employees is essential for them to survive and prosper in a continuously changing environment (Harter, Schmidt \& Keyes, 2002).

According to Lyubomirsky, Sheldon and Schkade (2005), three sets of factors affect a person's level of subjective well-being. These are a genetically determined set point, circumstantial factors and intentional activities and practices (Lyubomirsky et al., 2005). Lyubomirsky (2008) points out that the set point explains $50 \%$ of the variance in subjective well-being, whilst circumstances and intentional activities explain $10 \%$ and $40 \%$ respectively. Although interventions to promote subjective well-being should focus on the workplace, the intentional activities of a person explain a relatively large percentage of the variance in subjective well-being.

Peterson, Park and Seligman (2005) distinguished between three orientations to subjective wellbeing: pleasure, engagement and meaning. Engagement and meaning, as routes to subjective well-being, are under the direct control of the person and result in higher levels of subjective well-being (Park, Peterson \& Ruch, 2009).

Engagement is a psychological state of involvement, commitment and attachment to a work role (Macey \& Schneider, 2008). Engaging in activities (like a work role) results in fulfilment and contributes to subjective well-being (Peterson et al., 2005). Engaged employees are also more likely to have good relationships with their employers and lead them to have positive attitudes, intentions and behaviours (Saks, 2006). Work engagement predicts job performance and client satisfaction 
(Bakker, Schaufeli, Leiter \& Taris, 2008). Therefore, work engagement and how to increase it are important research topics (Rothmann \& Rothmann, 2010). Intentional activities (including the use of constructive coping strategies) offer opportunities for sustainably increasing engagement and subjective well-being (Lyubomirsky et al., 2005).

Coping is a relevant concept in the study of subjective wellbeing for two reasons.

Firstly, occupational stress impedes happiness at work. Work engagement is an important component of happiness. Therefore, one way to increase work engagement is to reduce the stress levels of employees (Schiffrin \& Nelson, 2010). Coping strategies play an important role in dealing with occupational stress. Consequently, people's coping strategies for dealing with occupational stress might affect their work engagement. Indeed, in the work engagement model of Kahn (1990), psychological availability (which results from dealing effectively with stress) has been found to be a strong antecedent of work engagement (May, Gilson \& Harter, 2004; Olivier \& Rothmann, 2007).

Secondly, the field of coping is broadening its scope towards positive striving emotions, goals and searching for meaning (Schwarzer \& Taubert, 2002). According to Schaufeli and Bakker (2004), research has shown that, even when exposed to high job demands and working long hours, some people show no symptoms of disengagement. Instead, they seem to find pleasure in dealing with these stressors - presumably because they have effective coping strategies.

The relationship between coping and positive outcomes (like work engagement) is not well understood (Folkman \& Moskowitz, 2004). We need research to expand the body of research - specifically into the relationship between coping strategies and positive outcomes (Schwarzer \& Taubert, 2002). We also need research to develop a deeper understanding of how different coping strategies relate to work engagement.

The objective of this study was to investigate the relationship between coping strategies and work engagement in three occupational groups in South Africa.

\section{Coping}

Coping has been conceived in several ways (Livneh, Antonak \& Gerhardt, 2000):

- as a personality trait and a situationally-determined response

- as a dynamic process and a static construct

- as a strategy that is mature, adaptive and flexible but also as a reaction that is neurotic, maladaptive and rigid

- as a global, generally dichotomous concept, but also as an intricate, hierarchically structured, multi-levelled concept.

According to Cooper, Dewe and O'Driscoll (2001), one should locate the definition of coping in transactional theory. Transactional theory sees coping as 'the thoughts and actions that are initiated in response to a specific encounter'
(Cooper et al., 2001, p. 160). In line with transactional theory, Lazarus and Folkman (1984) define coping as the efforts, both behavioural and cognitive, that people invest in order to deal with (to master, reduce and/or tolerate) stressful encounters. According to Carver and Scheier (1996), dealing with stress comprises three processes: primary appraisal, secondary appraisal and coping. Primary appraisal is the process of perceiving threats to the self. Secondary appraisal refers to the perceived availability of coping resources to deal with stressful encounters. Primary and secondary appraisals initiate coping behaviours.

Folkman and Lazarus (1980) suggest two general types of coping. The first is problem-focused coping. People find ways of reducing stress at its source by trying to prevent whatever is posing the threat from occurring. The second is emotionfocused coping. People feel that they must somehow tolerate the source of the stress and they try to manage or reduce the emotional discomfort associated with the situation. Emotionfocused coping emphasises interpreting a situation or how the person attends to it. Carver et al. (1989) propose a third style of coping: avoidant coping, which they integrated in a self-regulatory model of stress and coping (Carver \& Scheier, 1996).

The literature on coping often makes another distinction between active and avoidant coping strategies. Active coping strategies are either behavioural or psychological responses designed to change the nature of the stressors themselves or how one thinks about them. Avoidant coping strategies lead people into activities (like alcohol use) or mental states (like withdrawal) that keep them from addressing stressful events directly. Generally speaking, active coping strategies, whether behavioural or emotional, are better ways of dealing with stressful events. Avoidant coping strategies seem to be psychological risk factors, or markers, for adverse responses to stressful life events (Holahan \& Moos, 1986).

Some see avoidant coping strategies as less adaptive methods of coping. Denial (pretending the stressors are not present or that they are not causing any significant distress), mental disengagement (distracting ourselves from thinking about the goals with which the stressors are interfering) and behavioural disengagement (abandoning the goals with which the stressors are interfering) are examples of avoidant coping strategies.

Endler and Parker (1990) refer to avoidance as a third strategy that people may use to cope with stress. Avoidance can include person-orientated or task-orientated strategies. Avoidance differs from problem- and emotion-focused coping in that avoiding stressful situations removes people from them, whereas problem- and emotion-focused coping help people to manage the stressful situations whilst they remain in them (Kowalski \& Crocker, 2001).

The Coping Orientations to the Problems Experienced (COPE) scale describes 14 different coping methods and makes several distinctions within the overall categories of 
problem-focused and emotion-focused coping (Carver et al., 1989). The COPE scales comprise active coping; planning; seeking instrumental social support; seeking emotional social support; suppressing competing activities; turning to religion; positive reinterpretation and growth; restraint coping; resignation or acceptance; focus on, and venting of, emotions; denial; mental disengagement; behavioural disengagement; and alcohol or drug use.

Pienaar and Rothmann (2003) suggest that a 4-factor structure is the basis of the COPE questionnaire.

The first factor could be approach coping. It includes the three scales (active coping, planning and suppressing competing activities) in the original proposal or an assortment of the added scales from the cognitive coping factor.

The second factor could be social or emotional coping. It includes the three scales in the original proposal (seeking social support for emotional reasons, seeking social support for instrumental reasons and focusing on, and venting of, emotions) and has been recognised as the most frequently reproduced factor (Kallasmaa \& Pulver, 2000).

The third factor deals with avoidance coping and usually includes the three scales in the original proposal (denial, behavioural and mental disengagement). However, alcohol or drug disengagement also loaded onto this factor in six subsequent studies (Cook \& Heppner, 1997; Finch, Panter \& Caskie, 1999; Hudec-Kneeviæ, Kardum \& Vukmiroviæ, 1999; Mitchell \& Hastings, 2001; Phelps \& Jarvis, 1994; Sica, Novara, Dorz \& Sanavio, 1997).

The fourth factor covers turning to religion. It may be such a specific coping strategy that one cannot define it as an exclusive approach, either social or emotional or avoidant, because it probably serves the purpose of all of these. It could also be a very specific approach because of its function for the user.

Billings and Moos (1981) point out that one coping strategy may be enough to reduce stress. This may reduce the need to use other responses. For example, a person may first use a problem-solving strategy. If this succeeds in eliminating stress, there is no need to use other strategies like avoidance. It can distort the coping strategies and their relationships to outcomes.

\section{Coping and work engagement}

Work engagement is a multidimensional concept. It is a positive, fulfilling, work-related state of mind that vigour, dedication and absorption define.

Vigour refers to high levels of energy and mental resilience whilst working, a willingness to invest effort in one's work and persistence even in the face of difficulties. Dedication is a sense of significance, enthusiasm, inspiration, pride and challenge. Absorption means full concentration on, and being deeply engrossed in, one's work. Time passes quickly and one has difficulty detaching oneself from work (GonzálezRomá, Schaufeli, Bakker \& Lloret, 2006; Schaufeli, Salanova, González-Romá \& Bakker, 2002).

Furthermore, work engagement is not a momentary and specific state. It is a more persistent and pervasive affectivecognitive state that does not focus on a particular object, event, person or behaviour (Schaufeli et al., 2002). According to Bakker and Demerouti (2008), work engagement is an important indicator of occupational well-being.

There is limited research that assesses the relationship between coping and work engagement. The existing and relevant research focuses on students and/or teachers (see Gan, Yang, Zhou \& Zhang, 2007; Milot \& Ludden, 2009; Parker \& Martin, 2009). It highlights the need to investigate the correlation between different coping strategies and engagement. Based on an analysis of findings in various studies by Wrosch and Scheier (2003), one can expect that coping strategies will affect engagement in different life roles. Their results showed that people who are highly engaged use problem-focused coping strategies. If they cannot use problem-focused coping, they will turn to adaptive emotionfocused coping strategies.

The literature also states that, whilst cognitive and behavioural coping strategies are important for predicting engagement, proactive coping and preventive coping can reduce the effect that stress has on engagement (Gan et al., 2007; Parker \& Martin, 2009). According to Schwarzer and Taubert (2002), negative appraisals (like harm, loss or threat) do not precede proactive coping.

Proactive coping is an attempt to build up general resources that facilitate moving towards challenging goals, personal growth and engagement. Proactive people see demands and opportunities in the future but they do not appraise these negatively. Therefore, coping for proactive people becomes managing goals rather than managing risks. This results in productive arousal and positive energy (Schwarzer \& Taubert, 2002). Proactive coping correlated positively, and moderately to strongly, with two problem-orientated coping strategies that the COPE measures. These are active coping $(r=0.52)$ and planning $(r=0.45)$. Furthermore, proactive coping correlated negatively $(r=-0.54)$ with behavioural disengagement, an avoidance coping strategy (Schwarzer \& Taubert, 2002).

In a study by Parker and Martin (2009) of the effects of coping and buoyancy on teachers' work-related well-being and engagement, the results provided evidence that coping directly predicts work-related engagement. The results showed that cognitive and behavioural strategies did not predict teacher engagement to the same extent or in the same way. The cognitive coping strategies of mastery orientation and failure avoidance were stronger predictors of teacher engagement via direct and indirect effects than were the behavioural strategies of planning and self-handicapping 
(Parker \& Martin, 2009). All direct coping strategies (like planning that aims to meet the practical and logistic demands of a job most effectively or mastery orientation that aims at the adaptive cognitive perspectives of effort, process, mastery and development) will not necessarily lead to greater engagement. Furthermore, not all palliative strategies (like self-handicapping) are equally detrimental to engagement (Parker \& Martin, 2009).

Engaged employees are able to deal with the demands of their positions (Schaufeli \& Salanova, 2007). This characteristic provides a link between engagement and using problemfocused coping strategies. These normally occur when people feel in control of situations and that they are able to cope (Lazarus, 1993). The common mechanism in these two concepts suggests that there is a positive relationship between problem solving coping strategies and engagement. Lees (2009) found that, although social support is a form of effective coping, it does not relate significantly to work engagement. This is because the nature of social support may hinder work engagement.

The researchers used this background to formulate two hypotheses:

- Hypothesis 1: Problem-focused coping strategies relate positively to work engagement.

- Hypothesis 2: Avoidance coping strategies relate negatively to work engagement.

\section{Research design \\ Research approach}

The researchers used a quantitative approach to achieve their research objectives. More specifically, they used a cross-sectional design to collect data on coping and work engagement at a particular point in time from people in three different occupational groups (Rosnow \& Rosenthal, 1999).

Researchers collect data simultaneously (or within a short period) when they use a cross-sectional design. This design suits the descriptive and predictive functions associated with correlational research (Graziano \& Raulin, 2004).

\section{Research method}

\section{Research participants}

The researchers drew random and stratified samples $(N=3178)$ from electricity supply personnel, nurses and officers in the South African Police Service. Table 1 presents some of the characteristics of the participants.

Table 1 shows that $67.5 \%$ of participants were police officers and more than $60 \%$ were men. Almost half of the sample spoke Afrikaans.

\section{Measuring instruments}

The Coping Orientations to the Problems Experienced Questionnaire (Carver et al., 1989) measures both situational and dispositional coping strategies.
TABLE 1: Characteristics of the participants $(N=3178)$

\begin{tabular}{llll}
\hline Variable & Organisation & Frequency & $\mathbf{\%}$ \\
\hline Group & Electricity supply personnel & 215 & 6.80 \\
& Nurses & 818 & 25.70 \\
& Police officers & 2145 & 67.50 \\
\multirow{2}{*}{ Gender } & Men & 1923 & 61.20 \\
& Women & 1220 & 38.80 \\
\multirow{2}{*}{ Language } & Afrikaans & 1558 & 49.00 \\
& English & 489 & 15.50 \\
& Other & 1078 & 35.50 \\
\hline
\end{tabular}

In the present study, the researchers used the dispositional version. It consists of 53 items. Response choices ranged from 1 ('I usually don't do this at all') to 4 ('I usually do this a lot'). The COPE measures 14 coping strategies.

In previous South African research, Storm and Rothmann (2003) found acceptable alpha values. Its inter-item correlation coefficients varied between 0.25 (acceptance) and 0.65 (turning to religion). The internal consistencies for this questionnaire were acceptable. Pienaar and Rothmann (2003) found that a 4-factor structure underpins the COPE. The factors include approach coping (active coping, planning and suppressing competing activities), social or emotional coping (seeking social support for emotional reasons, seeking social support for instrumental reasons and focusing on, and venting of, emotions), avoidance coping (denial, behavioural disengagement, mental disengagement and alcohol or drug disengagement) and turning to religion (Pienaar \& Rothmann, 2003).

The Utrecht Work Engagement Scale (UWES) (Schaufeli et al., 2002) measures levels of work engagement.

The UWES covers three dimensions: vigour, dedication and absorption. They are conceptually regarded as the opposite of burnout and are scored on a 7-point frequency-rating scale, varying from 0 ('never') to 6 ('every day'). The questionnaire consists of 17 questions and includes statements like 'I am bursting with energy every day in my work', 'time flies when I am at work' and 'my job inspires me'.

The alpha coefficients for the three subscales varied between 0.68 and 0.91. Storm (2002) obtained the alpha coefficients that follow on the UWES in the South African Police Service: vigour (0.78), dedication (0.89) and absorption (0.78). Naudé and Rothmann (2004) obtained the alpha coefficients that follow on a sample of 405 emergency workers in South Africa: vigour (0.70), dedication (0.83) and absorption (0.67).

\section{Research procedure}

The researchers approached the managers of the organisations to obtain permission to conduct the study with their employees. The participants gave their informed consent. They indicated their willingness to participate in the study by signing a return slip. The researchers observed all the ethical guidelines for treating human subjects throughout the study. Fieldworkers administered the questionnaires to participants in the different organisations and collected the questionnaires immediately after they had completed them. 
The participants completed the questionnaires anonymously. The fieldworkers explained to the participants that the researchers would treat the questionnaires confidentially.

\section{Statistical analysis}

The researchers conducted the statistical analysis with the aid of the SPSS program (SPSS Inc., 2010). They performed exploratory factor analyses to investigate the construct validity of the measuring instruments.

The researchers first conducted a simple principal component analysis on the COPE. They studied the Eigenvalues and scree plot to determine the number of factors. In order to evaluate the construct validity of the COPE, they performed a principal axis factor analysis, with a varimax rotation, on the 53 items of the COPE (Tabachnick \& Fidell, 2001).

The researchers used descriptive statistics to explore the data. They assessed the internal consistencies of the measuring instrument using Cronbach alpha coefficients. Alpha coefficients convey important information about the amount of variance in a scale (Clark \& Watson, 1995).

The researchers used Pearson product-moment correlation coefficients to determine the relationship between the variables. The researchers set a confidence level of $95 \%$ $(p \leq 0.05)$ to test for statistical significance.

The researchers used effect sizes (Steyn, 1999) to determine the practical significance of the findings. They set a cut-off point of 0.30 (medium effect; Cohen, 1988) for the practical significance of the correlation coefficients. Because the sample sizes in the three occupational groups were substantially different, they computed Fisher $z$-values to compare the correlation coefficients between the constructs in the three groups. They multiplied the observed $p$-values by three because they conducted several tests (Ramseyer, 1979).

The researchers conducted hierarchical multiple regression analyses to determine the amount of variance in the dependent variable, which the independent variables predict. They used the value of $R^{2}$ to determine the amount of the total variance of the dependent variable, which the independent variables explain. They used the $F$-test test for a significant regression between the independent and dependent variables (Tabachnick \& Fidell, 2001).

\section{Results}

\section{Exploratory factor analyses}

The researchers performed a simple principal component analysis on the COPE items to determine the number of factors. An analysis of the Eigenvalues showed that they could extract nine factors. They explained $52.2 \%$ of the total variance. The researchers then performed a principal axis factor analysis, with a varimax rotation, on the 53 items of the COPE (see Table 2).

The researchers labelled the nine factors as problem-solving (factor 1), avoidance (factor 2), seeking support (factor 3), turning to religion (factor 4), suppressing competing activities (factor 5), acceptance (factor 6), ventilation (factor 7), positive reinterpretation and growth (factor 8) and behavioural disengagement (factor 9). The factor loadings were all higher than the cut-off point of 0.32 (Clark \& Watson, 1995). Most communalities were average to high. This indicates that the nine factors represent the items quite well.

The researchers performed a simple principal component analysis on the UWES items to determine the number of factors. An analysis of the Eigenvalues showed that they could extract one factor. It explained $51.29 \%$ of the total variance. The researchers then performed a principal axis factor analysis, with a varimax rotation, on the 17 items of the UWES (see Table 3). They labelled the factor work engagement. It comprises vigour, dedication and absorption.

\section{Descriptive statistics and alpha coefficients}

Table 4 reports the descriptive statistics, alpha coefficients and correlations of the COPE and UWES.

Table 4 shows high alpha coefficients that range from 0.60 to 0.94 . The alpha coefficients of most of the scales were higher than 0.70 . They indicate acceptable internal consistency (Nunnally \& Bernstein, 1994). However, the internal consistencies of four scales (suppressing competing activities, acceptance, ventilating emotions and positive reinterpretation and growth) were slightly lower than the recommended value. The reliability of one scale (behavioural disengagement) was 0.51 . Table 4 does not show it and the researchers decided to exclude this scale from further analyses.

Table 4 shows that work engagement has a statistically and practically significant relationship with problem-focused coping and with positive reinterpretation and growth (both medium effects). Work engagement also has a statistically significant relationship with seeking social support, turning to religion, suppressing competing activities and acceptance. Work engagement has a statistically and negatively significant relationship with ventilating emotions.

To compare the Pearson correlations of the three occupational groups, the researchers calculated Fisher $z$-values. They multiplied the $p$-values by three because they conducted several tests. Table 5 gives the results of the comparison.

With regard to the correlations between the coping factors, Table 5 shows that avoidance and turning to religion in the police sample have a statistically significant and stronger relationship with problem-focused coping compared to the nurses' group. Seeking social support and ventilating emotions in the police sample have a statistically significant and stronger relationship with avoidance coping compared to the nurses. Turning to religion in the police sample has a statistically significant and stronger relationship with 
TABLE 2: Principal component analysis with a varimax rotation on the COPE.

\begin{tabular}{|c|c|c|c|c|c|c|c|c|c|c|c|}
\hline Item & Description & F1 & F2 & F3 & F4 & F5 & F6 & F7 & F8 & F9 & $h^{2}$ \\
\hline 45 & I concentrate my efforts on doing something about it. & 0.74 & -0.01 & 0.19 & 0.10 & 0.12 & 0.06 & 0.10 & 0.02 & 0.04 & 0.62 \\
\hline 47 & I think hard about what steps to take. & 0.72 & 0.01 & 0.16 & 0.12 & 0.16 & 0.09 & 0.12 & 0.02 & -0.01 & 0.60 \\
\hline 35 & I try to come up with a strategy about what to do. & 0.66 & -0.09 & 0.30 & 0.10 & 0.09 & 0.16 & -0.05 & 0.11 & 0.08 & 0.60 \\
\hline 46 & $\begin{array}{l}\text { I stop myself from getting distracted by other thoughts or } \\
\text { activities. }\end{array}$ & 0.65 & 0.21 & 0.04 & 0.08 & 0.13 & -0.03 & 0.08 & 0.04 & 0.04 & 0.51 \\
\hline 43 & I learn something from the experience. & 0.56 & -0.02 & 0.24 & 0.18 & 0.09 & 0.28 & 0.03 & 0.15 & -0.08 & 0.53 \\
\hline 48 & I accept the reality that it happened. & 0.56 & -0.04 & 0.13 & 0.09 & 0.04 & 0.49 & 0.11 & -0.00 & -0.04 & 0.59 \\
\hline 32 & I take direction to get around the problem. & 0.53 & 0.05 & 0.13 & 0.100 & 0.09 & 0.14 & 0.03 & 0.19 & 0.13 & 0.38 \\
\hline 19 & $\begin{array}{l}\text { I try to prevent other things from interfering with my efforts } \\
\text { to deal with this. }\end{array}$ & 0.52 & 0.10 & 0.14 & 0.06 & 0.26 & -0.03 & -0.01 & 0.41 & 0.15 & 0.55 \\
\hline 23 & I do what I have to one step at a time. & 0.51 & -0.06 & 0.24 & 0.13 & 0.23 & 0.26 & 0.01 & 0.19 & 0.04 & 0.50 \\
\hline 38 & $\begin{array}{l}\text { I focus on dealing with the problem, and, if necessary, let } \\
\text { other things slide a little. }\end{array}$ & 0.47 & 0.14 & 0.12 & 0.17 & 0.08 & 0.08 & 0.12 & -0.09 & 0.41 & 0.49 \\
\hline 31 & I stop myself from doing anything too quickly. & 0.43 & 0.18 & 0.10 & 0.05 & 0.06 & 0.15 & -0.03 & 0.41 & 0.13 & 0.44 \\
\hline 29 & I pretend that it hasn't really happened. & 0.02 & 0.71 & -0.03 & 0.02 & -0.03 & 0.04 & 0.09 & 0.14 & 0.04 & 0.54 \\
\hline 42 & I act as though it hasn't even happened. & 0.14 & 0.71 & 0.012 & 0.08 & -0.05 & 0.08 & -0.07 & 0.00 & 0.05 & 0.54 \\
\hline 16 & I say to myself, 'This isn't real'. & 0.03 & 0.66 & 0.15 & 0.07 & 0.06 & -0.10 & 0.03 & 0.22 & 0.02 & 0.53 \\
\hline 50 & I just give up trying to reach my goal. & -0.02 & 0.66 & 0.05 & 0.04 & 0.02 & 0.04 & 0.13 & -0.16 & 0.02 & 0.48 \\
\hline 2 & I refuse to believe it happened. & 0.00 & 0.61 & 0.03 & -0.01 & 0.13 & -0.12 & 0.02 & 0.14 & -0.04 & 0.42 \\
\hline 26 & I give up trying to get what I want. & -0.03 & 0.59 & 0.10 & 0.04 & 0.03 & 0.17 & 0.18 & -0.10 & 0.12 & 0.45 \\
\hline 13 & I admit that I can't deal with it and stop trying. & -0.07 & 0.57 & 0.08 & 0.01 & 0.14 & -0.01 & 0.09 & 0.07 & 0.12 & 0.39 \\
\hline 52 & I daydream about other things. & 0.06 & 0.55 & 0.03 & 0.09 & -0.04 & 0.14 & 0.27 & -0.08 & 0.12 & 0.43 \\
\hline 39 & $\begin{array}{l}\text { I reduce the amount of effort I'm using to solving the } \\
\text { problem. }\end{array}$ & 0.10 & 0.52 & 0.12 & 0.10 & -0.04 & 0.09 & 0.04 & -0.07 & 0.30 & 0.40 \\
\hline 44 & I hold off doing anything about it until the situation permits. & 0.40 & 0.46 & 0.08 & 0.04 & 0.13 & 0.17 & -0.04 & -0.04 & 0.02 & 0.43 \\
\hline 12 & I drink alcohol or take drugs to think about it less. & -0.09 & 0.45 & -0.09 & -0.20 & 0.08 & -0.04 & 0.23 & 0.10 & 0.20 & 0.37 \\
\hline 49 & I discuss my feelings with someone. & 0.24 & 0.04 & 0.77 & 0.14 & 0.00 & 0.07 & 0.15 & 0.01 & 0.04 & 0.71 \\
\hline 8 & I talk to someone about how I feel. & 0.08 & 0.015 & 0.74 & 0.11 & 0.19 & 0.14 & 0.12 & 0.10 & 0.00 & 0.64 \\
\hline 15 & I try to get emotional support from friends and relatives. & 0.10 & 0.051 & 0.70 & 0.12 & 0.09 & 0.05 & 0.19 & 0.19 & 0.07 & 0.61 \\
\hline 34 & $\begin{array}{l}\text { I talk to someone who could do something concrete about } \\
\text { the problem. }\end{array}$ & 0.43 & 0.01 & 0.62 & 0.10 & 0.08 & 0.06 & -0.07 & -0.02 & 0.11 & 0.61 \\
\hline 28 & I get sympathy and understanding from someone. & 0.010 & 0.27 & 0.59 & 0.10 & -0.03 & 0.07 & 0.14 & 0.10 & 0.17 & 0.50 \\
\hline 1 & $\begin{array}{l}\text { I ask people who have had similar experiences what they } \\
\text { did. }\end{array}$ & 0.15 & 0.19 & 0.50 & 0.09 & 0.35 & -0.02 & -0.08 & 0.04 & 0.01 & 0.44 \\
\hline 14 & I let my feelings out. & 0.04 & 0.00 & 0.50 & 0.08 & 0.01 & 0.07 & 0.46 & 0.34 & 0.02 & 0.59 \\
\hline 51 & I seek God's help. & 0.21 & 0.08 & 0.14 & 0.84 & 0.05 & 0.04 & 0.03 & 0.03 & 0.02 & 0.78 \\
\hline 37 & I try to find comfort in my religion. & 0.21 & 0.10 & 0.15 & 0.78 & 0.10 & 0.03 & -0.01 & 0.02 & 0.21 & 0.73 \\
\hline 24 & I pray more than usual. & 0.13 & 0.12 & 0.12 & 0.77 & 0.03 & 0.06 & 0.12 & 0.9 & 0.17 & 0.68 \\
\hline 10 & I put my trust in God. & 0.17 & 0.01 & 0.15 & 0.75 & 0.21 & 0.13 & -0.03 & 0.11 & -0.08 & 0.70 \\
\hline 5 & I put aside other activities in order to concentrate on this. & 0.27 & 0.16 & 0.15 & 0.01 & 0.64 & -0.05 & 0.08 & -0.02 & 0.17 & 0.56 \\
\hline 6 & I take additional action to try to get rid of the problem. & 0.33 & -0.01 & 0.14 & 0.08 & 0.61 & 0.08 & 0.09 & 0.11 & 0.09 & 0.53 \\
\hline 4 & I force myself to wait for the right time to do something. & 0.19 & 0.21 & 0.09 & 0.11 & 0.60 & 0.19 & -0.07 & 0.08 & 0.04 & 0.50 \\
\hline 3 & I try to grow as a person as a result of the experience. & 0.29 & -0.08 & 0.17 & 0.21 & 0.42 & 0.26 & 0.09 & 0.19 & -0.18 & 0.49 \\
\hline 21 & I learn to live with it. & 0.22 & 0.09 & 0.07 & 0.09 & 0.10 & 0.65 & 0.01 & 0.13 & 0.13 & 0.53 \\
\hline 33 & I accept that this has happened and that I can't change it. & 0.27 & 0.16 & 0.11 & 0.04 & -0.00 & 0.63 & 0.01 & 0.08 & 0.12 & 0.53 \\
\hline 7 & I get used to the idea that it happened. & 0.14 & 0.05 & 0.14 & 0.03 & 0.39 & 0.55 & 0.09 & 0.05 & 0.10 & 0.52 \\
\hline 27 & I get upset and let my emotions out. & 0.02 & 0.23 & 0.22 & -0.03 & -0.03 & 0.06 & 0.71 & 0.09 & 0.09 & 0.62 \\
\hline 53 & I get upset and am really aware of it. & 0.19 & 0.30 & 0.00 & 0.06 & 0.09 & 0.06 & 0.65 & -0.18 & 0.06 & 0.61 \\
\hline 40 & $\begin{array}{l}\text { I feel a lot of emotional distress and I find myself expressing } \\
\text { those feelings a lot. }\end{array}$ & 0.10 & 0.33 & 0.17 & 0.07 & 0.07 & -0.03 & 0.59 & -0.10 & 0.15 & 0.54 \\
\hline 18 & I make sure not to make matters worse by acting too soon. & 0.42 & 0.09 & 0.12 & 0.05 & 0.19 & 0.06 & -0.10 & 0.54 & 0.07 & 0.54 \\
\hline 17 & $\begin{array}{l}\text { I try to see it in a different light to make it seem more } \\
\text { positive. }\end{array}$ & 0.32 & 0.08 & 0.23 & 0.14 & 0.12 & 0.22 & -0.03 & 0.51 & -0.00 & 0.51 \\
\hline 30 & I look for something good in what is happening. & 0.40 & 0.05 & 0.18 & 0.19 & -0.03 & 0.29 & -0.01 & 0.44 & 0.05 & 0.52 \\
\hline 36 & I go to the movies, watch TV or think about it. & 0.17 & 0.18 & 0.18 & 0.07 & 0.01 & 0.16 & 0.02 & -0.05 & 0.60 & 0.49 \\
\hline 11 & I sleep more than usual. & -0.10 & 0.25 & 0.07 & 0.07 & 0.17 & -0.01 & 0.13 & 0.15 & 0.54 & 0.44 \\
\hline 25 & $\begin{array}{l}\text { I turn to work or other substitute activities to take my mind } \\
\text { off things. }\end{array}$ & 0.17 & 0.22 & 0.04 & 0.16 & 0.04 & 0.21 & 0.18 & 0.19 & 0.47 & 0.45 \\
\hline \multicolumn{2}{|c|}{$\%$ of variance (total $=53.60 \%$ ) } & 12.81 & 4.88 & 2.43 & 2.10 & 1.50 & 1.32 & 1.27 & 1.07 & 1.02 & - \\
\hline
\end{tabular}

COPE, Coping Orientations to the Problems Experienced Scale.

Values in bold indicate that they are much higher than the others.

$h^{2}$ denotes communalities of the items. 
seeking social support compared to the nurses' group. Positive reinterpretation and growth in the police sample has a statistically significant and stronger relationship with ventilating emotions compared to the nurses' sample.

There are no statistically significant differences between work engagement and coping strategies in the different organisations. There are statistically significant correlations

\begin{tabular}{lcc} 
TABLE 3: Principal component analysis on the UWES. & \\
\hline Item & Component 1 & $\boldsymbol{h}^{\mathbf{2}}$ \\
\hline UWES1 & 0.59 & 0.35 \\
UWES2 & 0.77 & 0.59 \\
UWES3 & 0.62 & 0.39 \\
UWES4 & 0.80 & 0.65 \\
UWES5 & 0.83 & 0.69 \\
UWES6 & 0.59 & 0.35 \\
UWES7 & 0.82 & 0.67 \\
UWES8 & 0.76 & 0.58 \\
UWES9 & 0.78 & 0.61 \\
UWES10 & 0.77 & 0.60 \\
UWES11 & 0.75 & 0.56 \\
UWES12 & 0.68 & 0.47 \\
UWES13 & 0.79 & 0.63 \\
UWES14 & 0.75 & 0.56 \\
UWES15 & 0.69 & 0.47 \\
UWES16 & 0.58 & 0.33 \\
UWES17 & 0.56 & 0.31 \\
\hline
\end{tabular}

UWES, Utrecht Work Engagement Scale.

$h^{2}$ denotes communalities of the items. (practically significant, medium effects) between problemfocused coping and positive reinterpretation and growth on the one hand and work engagement on the other.

\section{Hierarchical regression analyses}

The researchers then performed hierarchical multiple regression analyses. In order to decide on the sequence of entering blocks of variables to the regression equation, the researchers conducted a simple principal component analysis on the eight scales of the COPE. An analysis of the Eigenvalues showed that they could extract two factors. This explained $60.93 \%$ of the total variance. They conducted a principal axis factor analysis, with a direct oblimin rotation, on the eight scales of the COPE. They extracted two factors: approach coping and avoidance coping.

Approach coping refers to strategies for resolving problems using problem-focused coping (loading $=0.93$ ), seeking social support (0.61), turning to religion (0.49), suppressing competing activities (0.65), acceptance (0.58) and positive reinterpretation and growth (0.80). Avoidance coping refers to strategies for resolving problems using avoidance (loading $=0.55)$ and ventilating emotions $(0.87)$.

The researchers decided to conduct separate multiple regression analyses for the three samples because of the differences in the correlations between coping strategies in

TABLE 4: Descriptive statistics, alpha coefficients and correlations between coping and work engagement in the total sample.

\begin{tabular}{|c|c|c|c|c|c|c|c|c|c|c|c|}
\hline Item & Mean & SD & $\alpha$ & 1 & 2 & 3 & 4 & 5 & 6 & 7 & 8 \\
\hline 1. Problem-focused coping & 35.80 & 7.00 & 0.88 & - & - & - & - & - & - & - & - \\
\hline 2. Avoidance & 22.05 & 6.59 & 0.83 & $0.21 *$ & - & - & - & - & - & - & - \\
\hline 3. Seeking social support & 24.91 & 6.31 & 0.87 & $0.59 * \div$ & $0.26 *$ & - & - & - & - & - & - \\
\hline 4. Turning to religion & 12.70 & 3.16 & 0.84 & $0.45 * \dagger$ & $0.18^{*}$ & $0.39 * \dagger$ & - & - & - & - & - \\
\hline 5. Suppressing competing activities & 11.70 & 2.76 & 0.67 & $0.59 * \ddagger$ & $0.22 *$ & $0.47 * \dagger$ & $0.32 * \dagger$ & - & - & - & - \\
\hline 6. Acceptance & 8.54 & 2.21 & 0.60 & $0.56 * \ddagger$ & $0.24 *$ & $0.38 * \dagger$ & $0.28 *$ & $0.43 * \dagger$ & - & - & - \\
\hline 7. Ventilating emotions & 7.04 & 2.36 & 0.68 & $0.22 *$ & $0.49 * \dagger$ & $0.34 * \dagger$ & $0.16 *$ & $0.21 *$ & $0.22 *$ & - & - \\
\hline 8. Positive reinterpretation and growth & 8.55 & 2.21 & 0.66 & $0.68 *$ & $0.19 *$ & $0.49 * \dagger$ & $0.37 * \dagger$ & $0.47 * \dagger$ & $0.45^{*} \dagger$ & $0.10^{*}$ & - \\
\hline 9. Work engagement & 73.01 & 19.64 & 0.94 & $0.37 * \dagger$ & -0.01 & $0.26 *$ & $0.21 *$ & $0.24^{*}$ & $0.20 *$ & $-0.06 *$ & $0.30 * \dagger$ \\
\hline
\end{tabular}

SD, standard deviation; $\alpha$, alpha coefficient.

$\dagger, r>0.30$ denotes practically significant (medium effect)

$\$, r>0.50$ denotes practically significant (large effect).

$*, p<0.01$

TABLE 5: Comparison of the correlations between coping and work engagement in three occupational groups.

\begin{tabular}{|c|c|c|c|c|c|c|c|c|c|c|c|c|c|c|c|c|c|c|c|c|c|c|c|c|}
\hline \multirow[t]{2}{*}{$\overline{\text { Organisation }}$} & \multicolumn{3}{|c|}{1} & \multicolumn{3}{|c|}{2} & \multicolumn{3}{|c|}{3} & \multicolumn{3}{|c|}{4} & \multicolumn{3}{|c|}{5} & \multicolumn{3}{|c|}{6} & \multicolumn{3}{|c|}{7} & \multicolumn{3}{|c|}{8} \\
\hline & 01 & 02 & 03 & 01 & 02 & 03 & 01 & 02 & 03 & 01 & 02 & 03 & 01 & 02 & 03 & 01 & 02 & 03 & 01 & 02 & 03 & 01 & 02 & 03 \\
\hline $\begin{array}{l}\text { 1. Problem-focused } \\
\text { coping }\end{array}$ & - & - & - & - & - & - & - & - & - & - & - & - & - & - & - & - & - & - & - & - & - & - & - & - \\
\hline $\begin{array}{l}\text { 3. Seeking social } \\
\text { support }\end{array}$ & 0.44 & $0.43 b$ & $0.65^{a}$ & 0.21 & $0.07^{\mathrm{b}}$ & $0.35^{\mathrm{a}}$ & - & - & - & - & - & - & - & - & - & - & - & - & - & - & - & - & - & - \\
\hline $\begin{array}{l}\text { 4. Turning to } \\
\text { religion }\end{array}$ & 0.38 & $0.28 b$ & $0.52^{\mathrm{a}}$ & 0.25 & 0.14 & 0.21 & 0.28 & $0.23^{b}$ & $0.46^{a}$ & - & - & - & - & - & - & - & - & - & - & - & - & - & - & - \\
\hline 5. Planning & 0.63 & 0.54 & 0.60 & 0.09 & 0.09 & 0.29 & 0.43 & 0.32 & 0.50 & 0.28 & 0.19 & 0.37 & - & - & - & - & - & - & - & - & - & - & - & - \\
\hline 6. Acceptance & 0.44 & 0.47 & 0.59 & 0.16 & 0.18 & 0.29 & 0.13 & 0.23 & 0.44 & 0.26 & 0.12 & 0.34 & 0.34 & 0.31 & 0.48 & - & - & - & - & - & - & - & - & \\
\hline $\begin{array}{l}\text { 7. Ventilating } \\
\text { emotions }\end{array}$ & 0.10 & 0.08 & 0.27 & 0.41 & $0.36^{b}$ & $0.58^{\mathrm{a}}$ & 0.32 & 0.28 & 0.36 & 0.23 & 0.09 & 0.18 & 0.09 & 0.10 & 0.25 & 0.06 & 0.08 & 0.27 & - & - & - & - & - & - \\
\hline $\begin{array}{l}\text { 8. Positive } \\
\text { reinterpretation } \\
\text { and growth }\end{array}$ & 0.61 & 0.64 & 0.70 & 0.13 & 0.04 & 0.26 & 0.54 & 0.31 & 0.35 & 0.30 & 0.27 & 0.41 & 0.43 & 0.40 & 0.50 & 0.30 & 0.40 & 0.18 & $-0.09-$ & $-0.10^{b}$ & $0.18 a$ & - & - & - \\
\hline $\begin{array}{l}\text { 9. Work } \\
\text { engagement }\end{array}$ & 0.34 & 0.36 & 0.37 & -0.03 & -0.11 & 0.02 & .14 & 0.19 & 0.29 & 0.10 & 0.11 & 0.25 & 0.30 & 0.21 & 0.25 & .10 & 0.21 & 0.20 & -0.10 & -0.10 & 0.19 & 0.32 & 0.30 & 0.30 \\
\hline
\end{tabular}

O1, technicians; $\mathrm{O} 2$, nurses; 03 , police officers.

a, Denotes a statistically significant difference $(p<0.01)$ from the correlation where, ${ }^{\mathrm{b}}$, is indicated. 
the three organisations. They followed a two-step multiple regression procedure.

In step 1, the researchers assessed the contribution to work engagement of the approach coping strategies:

- problem-focused coping

- seeking social support

- turning to religion

- suppressing competing activities

- acceptance and positive reinterpretation

- growth.

In step 2, they assessed the contribution to work engagement of avoidance coping strategies: avoidance and ventilating emotions. Table 6 gives the results.

Table 6 shows that approach coping strategies predicted 15\% of the variance in the work engagement of the technicians $(F=6.25, p<0.01)$. The regression coefficients of two coping strategies, namely problem-focused coping $(\beta=0.21, p<0.01)$ and positive reinterpretation and growth $(\beta=0.17, p<0.01)$, were statistically significant. When the researchers entered avoidance coping strategies as independent variables (in step 2), it resulted in a statistically significant increase in predicting the variance in work engagement $(\Delta F=4.90, p$ $\left.<0.01, \Delta R^{2}=0.04\right)$. The regression coefficients of two coping strategies, namely problem-focused coping $(\beta=0.23, p<0.01)$ and ventilating emotions $(\beta=-0.23, p<0.01)$, were statistically significant.

Furthermore, approach coping strategies predicted 14\% of the variance in the work engagement of the nurses $(F=22.24, p<0.01)$. The regression coefficients of two coping strategies, namely problem-focused coping $(\beta=0.26, p<0.01)$ and positive reinterpretation and growth $(\beta=0.11, p<0.01)$, were statistically significant. When the researchers entered avoidance coping strategies as independent variables (in step 2), it resulted in a statistically significant increase in predicting the variance in work engagement $(\Delta F=14.51$, $\left.p<0.01, \Delta R^{2}=0.03\right)$. The regression coefficients of three coping strategies, namely problem-focused coping $(\beta=0.23$, $p<0.01)$, avoidance $(\beta=0.10, p<0.01)$ and ventilating emotions $(\beta=-0.12, p<0.01)$, were statistically significant.

Finally, approach coping strategies predicted $15 \%$ of the variance in the work engagement of the police officers $(F=62.49, p<0.01)$. The regression coefficients of five coping strategies, namely, (1) problem-focused coping $(\beta=0.27$, $p<0.01)$, (2) seeking social support $(\beta=0.05, p<0.05)$, (3) turning to religion $(\beta=0.07, p<0.05),(4)$ acceptance $(\beta=-0.05$, $p<0.05)$ and (5) positive reinterpretation and growth $(\beta=0.11$, $p<0.01$ ), were statistically significant. When the researchers added avoidance coping strategies as independent variables (in step 2), it resulted in a statistically significant increase in predicting the variance in work engagement $(\Delta F=33.10$, $p<0.01, \Delta R^{2}=0.03$ ). The regression coefficients of four coping strategies, namely, (1) problem-focused coping $(\beta=0.27$, $p<0.01)$, (2) seeking social support $(\beta=0.11, p<0.01)$, (3) turning to religion $(\beta=0.07, p<0.05)$ and $(4)$ ventilating emotions $(\beta=-0.15, p<0.01)$, were statistically significant.

The results support Hypothesis 1 and Hypothesis 2.

With regard to Hypothesis 1, problem-focused coping was statistically significant and positively related to the work engagement of the technicians, nurses and police officers. In addition, two other coping strategies, seeking social support and turning to religion, were statistically significant and positively related to the work engagement of the police officers.

With regard to Hypothesis 2, ventilating emotions (a type of avoidance coping strategy) was statistically significant and related negatively to the work engagement of all three groups. However, avoidance also predicted the low work engagement of nurses.

\section{Discussion}

The objective of this study was to investigate the relationship between coping strategies and work engagement in three occupational groups. These were technical employees in an

TABLE 6: Regression analyses with coping strategies as the independent variables and work engagement as the dependent variable.

\begin{tabular}{|c|c|c|c|c|c|c|}
\hline \multirow[t]{2}{*}{ Variable } & \multicolumn{2}{|c|}{ Technicians } & \multicolumn{2}{|c|}{ Nurses } & \multicolumn{2}{|c|}{ Police officers } \\
\hline & Step 1 & Step 2 & Step 1 & Step 2 & Step 1 & Step 2 \\
\hline Constant & 33.53 & 40.06 & 29.03 & 38.09 & 34.05 & 39.12 \\
\hline Problem-focused coping & $0.21 *$ & $0.23 *$ & $0.26 * *$ & $0.26 * *$ & $0.27 * *$ & $0.27 * *$ \\
\hline Seeking social support & -0.05 & 0.03 & 0.03 & 0.07 & $0.05 *$ & $0.11 * *$ \\
\hline Turning to religion & -0.04 & -0.01 & -0.00 & 0.02 & $0.07 *$ & $0.07 * *$ \\
\hline Planning & 0.16 & 0.15 & 0.02 & 0.03 & 0.03 & 0.04 \\
\hline Acceptance & -0.08 & -0.07 & 0.03 & 0.06 & $-0.05 *$ & -0.03 \\
\hline Positive reinterpretation and growth & $0.17 *$ & 0.10 & $0.11 * *$ & 0.06 & $0.06 *$ & 0.05 \\
\hline Avoidance & - & 0.03 & - & $-0.10 * *$ & - & -0.04 \\
\hline Ventilating emotions & - & $-0.23 * *$ & - & $-0.12 * *$ & - & $-0.15 * *$ \\
\hline$R^{2}$ & 0.15 & 0.19 & 0.14 & 0.17 & 0.15 & 0.18 \\
\hline$F$ & $6.25 * *$ & $6.09 * *$ & 22.24 & $20.86 * *$ & 62.49 & $56.55 * *$ \\
\hline$\Delta R^{2}$ & - & 0.04 & - & 0.03 & - & 0.03 \\
\hline$\Delta F$ & - & $4.90 * *$ & - & $14.51 * *$ & - & $33.10 * *$ \\
\hline
\end{tabular}

${ }^{*}, p<0.05 ;{ }^{* *}, p<0.01$ 
electricity provider, professional and enrolled nurses and police officers in the South African Police Service. The results showed that eight coping strategies, which the researchers extracted using exploratory factor analyses, were sufficiently reliable for them to conduct analyses for the purposes of this study.

One can classify these coping strategies as approaching strategies (like problem-focused coping, seeking social support, turning to religion, suppressing competing activities, acceptance and positive reinterpretation and growth) and avoiding strategies (like avoidance and ventilating emotions). The coping strategies did not have a differential relationship with work engagement in the three organisations.

As far as approach coping strategies in this study are concerned, problem-focused coping means that employees take active steps to try to remove stressors, get round them, restructure them, accept situations, learn from their experiences and suppress competing activities.

In this study, seeking support as a coping strategy included two types of strategies. These were seeking support for instrumental reasons (seeking advice, assistance and/or information) and seeking support for emotional reasons (seeking moral support and/or understanding); see Carver et al. (1989). Suppressing competing activities refers to putting other projects aside and trying to avoid distractions from other events in order to deal with stressors. Acceptance means that employees accept the reality of stressful situations. Positive reinterpretation and growth aims to deal with distress emotions rather than dealing with stressors. However, it might also lead employees to reconstruct situations positively. Turning to religion might serve as a source of emotional support, as a way of reinterpreting stressful situations in positive terms and as a tactic to deal actively with stressors. In this study, avoidance coping included avoiding and denying the reality of events as well as ventilating emotions. According to Carver et al. (1989), ventilating emotions means that employees focus on the distress that they are experiencing and release their emotions. Focusing on these emotions can hinder adjustment.

Approach coping strategies predicted approximately 15\% of the variance in work engagement for all three organisations. Two approach coping strategies seem to play an important role in engaging at work in all three organisations. These are problem-focused coping and positive reinterpretation and growth.

These two coping strategies seem to involve proactive coping (Schwarzer \& Taubert, 2002). Proactive people appraise future demands and opportunities positively. Therefore, they experience vigour, dedication and absorption because they manage their goals by tackling problems and through positive interpretation and growth. Schwarzer and Taubert (2002) reported similar findings in their study. When the researchers considered avoidance coping strategies with approach coping strategies, only problem-focused coping showed a positive relationship with work engagement. Therefore, employees who cope by using strategies to solve problems and by positively reinterpreting and growing from experiences are more engaged in their work.

When the researchers entered both approach and avoidance coping strategies to the regression equations, problemfocused coping and low ventilation of emotions were the best predictors of work engagement in the technician sample.

In the nursing sample, one approach coping strategy (problemfocused coping) and two avoidance coping strategies (low avoidance and low ventilation of emotions) predicted work engagement. In the nursing sample, the presence of approach coping strategies related to work engagement. However, the absence of avoidance coping strategies also did. Nurses who do not deny the reality of events and who do not express their emotions are more engaged in their work.

In the police sample, three approach coping strategies (problem-focused coping, seeking social support and turning to religion) predicted work engagement. One avoidance coping strategy (ventilating emotions) contributed to disengagement at work. These results suggest that preventive coping (in problem-focused coping and low avoidance coping, like ventilating emotions and denying the reality of situations) contributes to work engagement (Gan et al., 2007; Parker \& Martin, 2009).

Based on the results of this study, it seems that coping has two pathways to work engagement: proactive and preventive (see Schwarzer \& Taubert, 2002). Parker and Martin (2009) found that mastery orientation and failure avoidance were strong predictors of work engagement.

One can classify these coping strategies as parts of the preventive coping pathway (similar to the problemfocused coping and low ventilation coping strategies in this study). On the other hand, one can classify approach coping strategies (like problem-focused coping and positive reinterpretation and growth) as parts of the proactive coping pathway (Schwarzer \& Taubert, 2002).

Although researchers have studied coping strategies in relation to stress, the results of this study suggest that coping strategies also affect the engagement of employees. It seems that employees who participate in positive, active coping strategies are able to maintain high levels of work engagement, whilst those who do not participate in such strategies experience decreased work engagement (Schiffrin \& Nelson, 2010).

\section{Recommendations}

The researchers recommend that organisations consider coping strategies to promote the work engagement of employees in different occupations in South Africa. Training programmes on coping skills should be implemented for police officers, nurses and technicians as part of a strategy to increase their work engagement. 


\section{Limitations of the study}

A limitation of this study was that $67.5 \%$ of the participants belonged to the same group, the police service. A very small sample came from the electricity supply organisation (6.8\%). Although the scores were standardised, the smaller sample could have influenced the results.

The research design was a cross-sectional survey one. This made it difficult to determine causal relationships. Longitudinal designs can help to establish causality.

Another limitation was that the researchers relied exclusively on self-reports.

Future studies should use samples that are more representative to study the relationships between coping and work engagement. Future research should study the purpose and effectiveness of coping strategies in relation to work engagement in different occupations (Kowalski \& Crocker, 2001). Researchers should study several factors in different occupations and organisations (like the type of work, management style and history) in research of this kind. They will provide an invaluable understanding of coping strategies and their relationships with work engagement.

\section{References}

Bakker, A.B., \& Demerouti, E. (2008). Towards a model of work engagement. Career Development International, 13(3), 209-233. doi:10.1108/13620430810870476

Bakker, A.B., Schaufeli, W.B., Leiter, M.P., \& Taris, T.W. (2008). Work engagement: An emerging concept in occupational health psychology. Work \& Stress, 22, 187-200. doi:10.1080/02678370802393649

Billings, A.G., \& Moos, R.H. (1981). The role of coping responses and social resources in attenuating the stress of life events. Journal of Behavioral Medicine, 4, 139157. doi:10.1007/BF00844267, PMid:7321033

Carver, C.S., \& Scheier, M.F. (1996). Self-regulation and its failures. Psychology Inquiry, 7, 32. doi:10.1207/s15327965pli0701_6

Carver, C.S., Scheier, M.F., \& Weintraub, J.K. (1989). Assessing coping strategies: A theoretically based approach. Journal of Personality and Social Psychology, 56, 267-283. doi:10.1037/0022-3514.56.2.267, PMid:2926629

Clark, L.A., \& Watson, D. (1995). Construct validity: Basic issues in objective scale development. Psychological Measurement, 28, 61-75.

Cohen, J. (1988). Statistical power analysis of the behavioural sciences. (2nd edn.). Orlando, CA: Academic Press.

Cook, S.W., \& Heppner, P.P. (1997). A psychometric study of three coping measures. Educational and Psychological Measurement, 57, 906-923. doi:10.1177/0013164497057006002

Cooper, C.L., Dewe, P.J., \& O'Driscoll, M.P. (2001). Organizational stress: A review and critique of theory, research, and applications. San Francisco, CA: Sage.

Endler, N.S., \& Parker, J.D.A. (1990). Coping Inventory for Stressful Situations (CISS): Manual. Toronto: Multi-Health Systems.

Finch, J.F., Panter, A.T., \& Caskie, G.I.L. (1999). Two approaches for identifying shared personality dimensions across methods. Journal of Personality, 67, 407-438. doi:10.1111/1467-6494.00060

Folkman, S., \& Lazarus, R.S. (1980). An analysis of coping in a middle-aged community sample. Journal of Health and Social Behavior, 21, 219-239. doi:10.2307/2136617, PMid:7410799

Folkman, S., \& Moskowitz, J.T. (2004). Coping: Pitfalls and promises. Annual Review of Psychology, 55, 745-774. doi:10.1146/annurev.psych.55.090902.141456, PMid:14744233

Gan, Y., Yang, M., Zhou, Y., \& Zhang, Y. (2007). The two-factor structure of futureoriented coping and its mediating role in student engagement. Personality and Individual Differences, 43, 851-863. doi:10.1016/j.paid.2007.02.009

González-Romá, V., Schaufeli, W.B., Bakker, A.B., \& Lloret, S. (2006). Burnout and work engagement: Independent factors or opposite poles? Journal of Vocational Behavior, 68, 165-174. doi:10.1016/j.jvb.2005.01.003

Graziano, A.M., \& Raulin, M.L. (2004). Research methods: A process of inquiry. (5th edn.). Upper Saddle River, NJ: Pearson Education Group.

Harter, J.K., Schmidt, F.L., \& Keyes, C.L. (2002). Well-being in the workplace and its relationship to work outcomes: A review of the Gallup studies. In C.L. Keyes \& J. relationship to work outcomes: A review of the Gallup studies. In C.L. Keyes \& J.
Haidt (Eds.), The positive person and the good life (pp. 205-224). Washington, DC: Haidt (Eds.), The positive person and
American Psychological Association.
Holahan, C.J., \& Moos, R.H. (1986). Personality, coping and family resources in stress resistance: A longitudinal analysis. Journal of Personality and Social Psychology, 51,389-395. doi:10.1037/0022-3514.51.2.389, PMid:3746619

Hudec-Kneeviæ, J., Kardum, I., \& Vukmiroviæ, Z. (1999). The structure of coping styles: A comparatively study of a Croatian sample. European Journal of Personality 13 , 149-161 doi:10.1002/(SICI)1099-0984(199903/04)13:2<149::AID PER326>3.0.CO·2-Z

Kahn, W.A. (1990). Psychological conditions of personal engagement and disengagement at work. Academy of Management Journal, 33, 692-724 doi:10.2307/256287

Kallasmaa, T., \& Pulver, A. (2000). The structure and properties of the Estonian COPE inventory. Personality and Individual Differences, 29, 881-894. doi:10.1016/ S0191-8869(99)00240-8

Kowalski, K.C., \& Crocker, P.R.E. (2001). Development and validation of the Coping Function Questionnaire for adolescents in sport. Journal of Sport and Exercise Psychology, 23, 136-155.

Lazarus, R.S. (1993). Coping theory and research: Past, present, and future Psychosomatic Medicine, 55, 234-247. PMid:8346332

Lazarus, R.S. (1966). Psychological stress and the coping process. New York: McGrawHill.

Lazarus, R.S., \& Folkman, S. (1984). Stress, appraisal, and coping. New York: Springer.

Lees, N.F. (2009). The ability to bounce back: The relationship between resilience, coping, and positive outcomes. Unpublished master's thesis, Massey University, Auckland

Livneh, H., Antonak, R.F., \& Gerhardt, J. (2000). Multidimensional investigation of the structure of coping among people with assumptions. Psychometrics, 41, 235-244.

Lyubomirsky, S. (2008). The how of happiness: A scientific approach to getting the life you want. New York: Penguin Press.

Lyubomirsky, S., Sheldon, K.M., \& Schkade, D. (2005). Pursuing happiness: The architecture of sustainable change. Review of General Psychology, 9, 111-113. doi:10.1037/1089-2680.9.2.111

Macey, W.H., \& Schneider, B. (2008). The meaning of employee engagement. Industrial and Organizational Psychology, 1, 3-30. doi:10.1111/j.1754-9434.2007.0002.x

May, D.R., Gilson, R.L., \& Harter, L.M. (2004). The psychological conditions of meaningfulness, safety and availability and the engagement of the human spirit at work. Journal of Occupational and Organizational Psychology, 77, 11-37. doi:10.1348/096317904322915892

Milot, A.S., \& Ludden, A.B. (2009). The effects of religion and gender on well-being, substance use, and academic engagement among rural adolescents. Youth \& Society, 40, 403-425. doi:10.1177/0044118X08316668

Mitchell, G., \& Hastings, R.P. (2001). Coping, burnout, and emotion in staff working in community services for people with challenging behaviors. American Journal on Mental Retardation, 106, 448-459. doi:10.1352/0895-8017(2001)106<0448:CBA EIS>2.0.CO;2

Naudé, J.L.P., \& Rothmann, S. (2004). The validation of the Utrecht Work Engagement Scale for emergency health technicians in Gauteng. South African Journal of Economic and Management Sciences, 7, 459-468.

Nunnally, J.C., \& Bernstein, I.H. (1994). Psychometric theory. (3rd edn.). New York: McGraw-Hill.

Olivier, A.L., \& Rothmann, S. (2007). Antecedents of work engagement in a multinational oil company. SA Journal of Industrial Psychology/SA Tydskrif vir Bedryfsielkunde, 33(3), 49-56.

Park, N., Peterson, C., \& Ruch, W. (2009). Orientations to happiness and life satisfaction in twenty-seven nations. The Journal of Positive Psychology, 4, 273279. doi:10.1080/17439760902933690

Parker, P.D., \& Martin, A.J. (2009). Coping and buoyancy in the workplace: Understanding their effects on teachers' work-related well-being and engagement. Teaching and Teacher Education, 25, 68-75. doi:10.1016/j.tate.2008.06.009

Peterson, C., Park, N., \& Seligman, M.E.P. (2005). Orientations to happiness and life satisfaction: The full life versus the empty life. Journal of Happiness Studies, 6 , 25-41. doi:10.1007/s10902-004-1278-z

Phelps, S.B., \& Jarvis, P.A. (1994). Coping in adolescence: Empirical evidence for a theoretically based approach to assessing coping. Journal of Youth and Adolescence, 23, 359-371. doi:10.1007/BF01536724

Pienaar, J., \& Rothmann, S. (2003). Coping strategies in the South African Police Service. SA Journal of Industrial Psychology/SA Tydskrif vir Bedryfsielkunde, 29(4), 81-90.

Ramseyer, G.C. (1979). Testing the difference between dependent correlations using the Fisher Z. The Journal of Experimental Education, 47, 307-310.

Rosnow, R.L., \& Rosenthal, R. (1999). Beginning behavioral research: A conceptual primer. (3rd edn.). Englewood Cliffs, NJ: Prentice-Hall.

Rothmann, S., \& Rothmann, S. (Jr). (2010). Factors associated with employee engagement in South African organisations. SA Journal of Industrial Psychology/ SA Tydskrif vir Bedryfsielkunde, 36(1), 1-12. doi:10.4102/sajip.v36i1.925

Saks, A.M. (2006). Antecedents and consequences of employee engagement. Journal of Managerial Psychology, 21(7), 600-619. doi:10.1108/02683940610690169

Schaufeli, W.B., \& Bakker, A.B. (2004). Job demands, job resources, and their relationship with burnout and engagement: A multi-sample study. Journal of Organisational Behavior, 25, 293-315. doi:10.1002/job.248

Schaufeli, W.B., \& Salanova, M. (2007). Work engagement: An emerging psychological concept and its implications for organizations. In S.W. Gilliland, D.D. Steiner \& D.P. Skarlicki (Eds.), Managing social and ethical issues in organizations, Volume 5: Research in social issues in management (pp. 135-177). Greenwich, CT: Information Age Publishers. 
Schaufeli, W.B., Salanova, M., González-Romá, V., \& Bakker, A.B. (2002). The measurement of engagement and burnout: A two sample confirmatory
factor analytic approach. Journal of Happiness Studies, 3, 71-92. factor analytic approach.
doi:10.1023/A:1015630930326

Schiffrin, H.H., \& Nelson, S.K. (2010). Stressed and happy: Investigating the relationship between happiness and perceived stress. Journal of Happiness Studies, 11, 22-39. doi:10.1007/s10902-008-9104-7

Schwarzer, R., \& Taubert, S. (2002). Tenacious goal pursuits and striving toward personal growth: Proactive coping. In E. Frydenberg (Ed.), Beyond coping: Meeting goals, visions and challenges (pp. 19-35). London: Oxford University Press.

Sica, C., Novara, C., Dorz, S., \& Sanavio, E. (1997). Coping strategies: Evidence fo cross- cultural differences? A preliminary study with the Italian version of coping orientations to problem experienced (COPE). Personality and Individual Differences, 23, 1025-1029. doi:10.1016/S0191-8869(97)00112-8

SPSS 18.0 [computer software] (2010). Chicago, IL: SPSS Incorporated.
Steyn, H.S. (1999). Praktiese betekenisvolheid: Die gebruik van effekgroottes [Practical significance: The use of effect sizes]. Wetenskaplike bydraes - Reeks B Natuurwetenskappe Nr. 117. Potchefstroom: PU vir CHO.

Storm, K. (2002). Burnout and work engagement in the South African Police Service. Unpublished doctoral thesis, PU for CHE, Potchefstroom, South Africa.

Storm, K., \& Rothmann, S. (2003). The relationship between burnout, personality traits and coping strategies in a corporate pharmaceutical group. SA Journal of Industrial Psychology/SA Tydskrif vir Bedryfsielkunde, SA Journal of Industrial Industrial Psychology/SA Tydskrif vir Bedryfsielkunde, SA J
Psychology/SA Tydskrif vir Bedryfsielkunde, 29(4), 35-42.

Tabachnick B.G., \& Fidell, L.S. (2001). Using multivariate statistics. (4th edn.). Boston, MA: Allyn \& Bacon.

Wrosch, C., \& Scheier, M.F. (2003). Personality and quality of life: The importance of optimism and goal adjustment. Quality of Life Research, 12, 59-72. doi:10.1023/A:1023529606137, PMid:12803312 